\title{
Altered Endocrine Biomarkers in Selected Fish Species in the Hudson River, New York
}

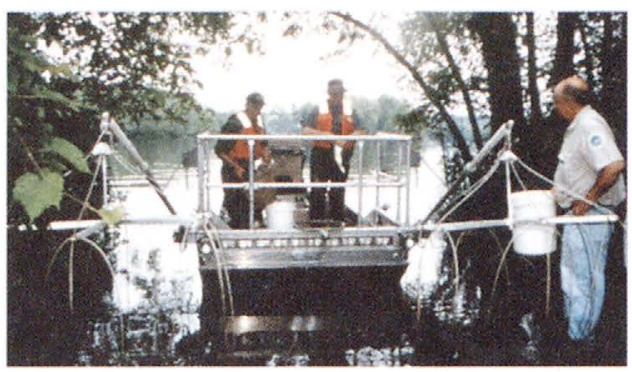

Electrofishing boat used to collect fish from Hudson River.

\section{Background}

An environmental endocrine disruptor is defined as an exogenous agent that interferes with the synthesis, secretion, transport, binding, action, or elimination of natural hormones in the body that are responsible for the maintenance of homeostasis, reproduction, development and/or behavior (U.S. Environmental Protection Agency, 1997).

Interest in the effects that contaminants may have on the endocrine system of aquatic organisms has increased considerably during the past two decades because:

- More chemicals are being identified as potential endocrine disrupters;

- These chemical contaminants are common and widespread in aquatic ecosystems; and

- The endocrine system of humans may also be negatively affected by environmental contaminants.

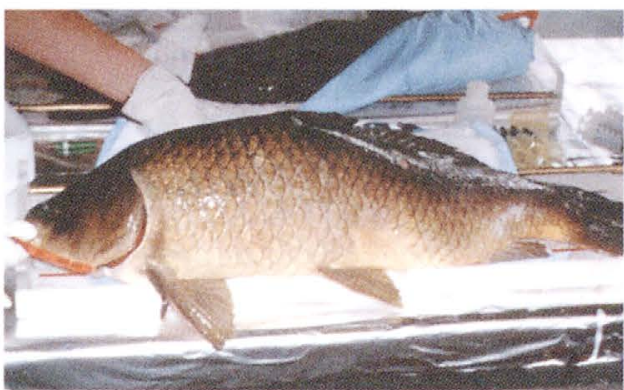

Carp collected from the Hudson River.
Information from a national reconnaissance investigation conducted in 1994-95 by the U.S. Geological Survey (USGS) indicates endocrine disruption in carp (Cyprinus carpio) is evident in several areas of the United States (Goodbred and others, 1997). Analyses of largemouth bass (Micropterus salmoides) and carp collected as part of the national reconnaissance, at three locations on the mainstem of the Hudson River in Fall 1994 and Spring 1995 - at Lake Luzerne, Catskill, and Poughkeepsie (fig. 1) indicated altered biomarkers (vitellogenin 17- $\beta$ estradiol, 11-ketotestosterone, and histo-pathology) in fish, particularly in areas with elevated concentrations of contaminants in the fish tissue and sediments (Smith and others, 1997).

\section{Problem/Objectives}

Polychlorinated biphenyls (PCBs) have been identified as one of the synthetic compounds that may impact the endocrine system of fish (U.S. Environmental Protection Agency, 1997). PCB concentrations in Hudson River sediments are highest in the upper reaches below $\mathrm{Ft}$. Edward and decrease with increasing distance downstream (Phillips and others, 1997).

Several programs are currently underway or proposed for monitoring contaminants in fish, sediments, and water in the Hudson River Basin. No studies were initially planned to document:

- Whether in-place pollutants in the Hudson River may cause altered endocrine biomarkers in resident fish;

- The magnitude and spatial extent of altered endocrine biomarkers in selected fish species in the Hudson River basin: and

- The potential for consequential endocrine disruption in other organ isms, including humans, that are exposed to the same environmental conditions or that consume Hudson River fish

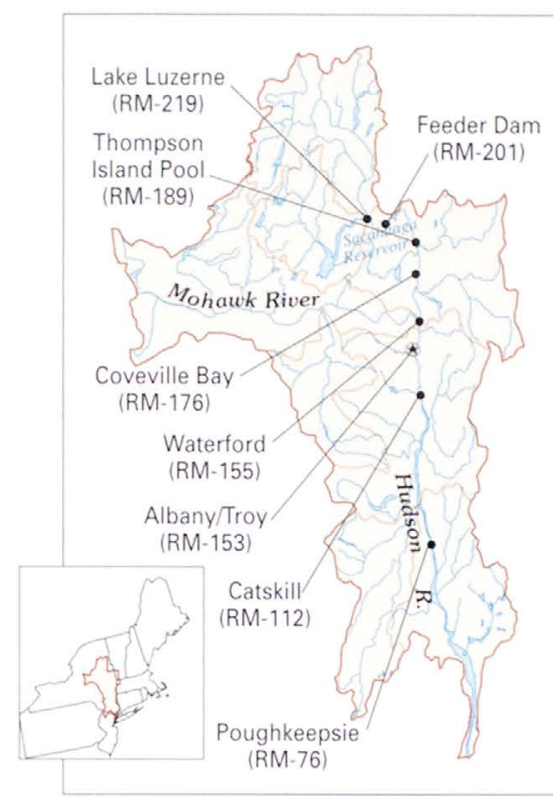

Figure 1. Endocrine study sites in the Hudson River basin (RM=river miles from mouth).

Since the 1994 and 1995 reconnaissance, additional analyses of histopathology and endocrine biomarker information have provided valuable base-line data. These data will gage effects that any future redistribution and/or cleanup of contaminated sediments in parts of the Hudson River system may have on the endocrine system of resident aquatic biota.

The objectives of these investigations of Hudson River fish are to:

- Determine the spatial extent and magnitude of altered endocrine biomarkers in three fish species (carp, black bass - largemouth and smallmouth [M. salmoides and M. dolomieui], and brown bullhead [Ameiurus nebulosus]) from selected sites on the Hudson River during the reproductive period; and

- Examine relation of contaminants in fish tissue and sediments to altered endocrine biomarkers in fish, including vitellogenin, 17- $\beta$ estradiol, 11-ketotestosterone, and histopathology. 


\section{Approach and Preliminary Results}

In 1998, USGS and New York State Department of Environmental Conservation collected blood and gonads from adult fish (black bass, brown bullhead, and carp) at several locations (fig, 1) on the mainstem Hudson River. A minimum of 20 fish from each site ( 10 of each sex) for each fish species was the target for collections. Endocrine biomarker and PCB tissue residue concentrations at the most contaminated sites (fig. 2) were compared to reference conditions with low concentrations of contaminants at sites near Lake Luzerne (RM-220) and the Feeder Dam (RM-201).

Endocrine biomarker, sediment residue, fish tissue residue, histopathology, and ancillary data are being compared and analyzed by correlation analyses and partial regression (fig. 2). Preliminary results (Baldigo and others, 2000) indicate that:

- PCB concentrations were highest in fish tissues and bed sediment at sites downstream from a major contaminant source (Thompson Island Pool,

Coveville Bay and Waterford are located from RM-155 to RM-189);

- PCB concentrations in bed sediment $(0$ $2500 \mu \mathrm{g} / \mathrm{kg}$ [micrograms per kilogram]) were strongly correlated with lipid based (normalized) PCB levels in fish tissues (200-1250 $\mu \mathrm{g} / \mathrm{g}$ [micrograms per gram]):

- Vitellogenin (precursor of yolk protein in females) was detected in plasma of male carp and bass at sites upstream and downstream from a known contaminant source; and

- The 17- $\beta$ estradiol/11-ketotestosterone (E/1 l-KT) ratio was abnormally high in all male bass at one site, and in about one third of male carp and bullhead at several other sites.

Related effects of contaminated sediments on gametogenesis may affect the health of the fish populations in parts of the Hudson River. Additional physiology and contaminant data are needed to fully document the natural variability (seasonal, annual, and interspecific) of reproductive biomarkers, the specific contaminants that could potentially affect endocrine systems, and the biological consequences of potential endocrine disruption in target fish and their populations of the Hudson River. Additional collections of fish will be required to define further spatial distribution and determine effects that alterations

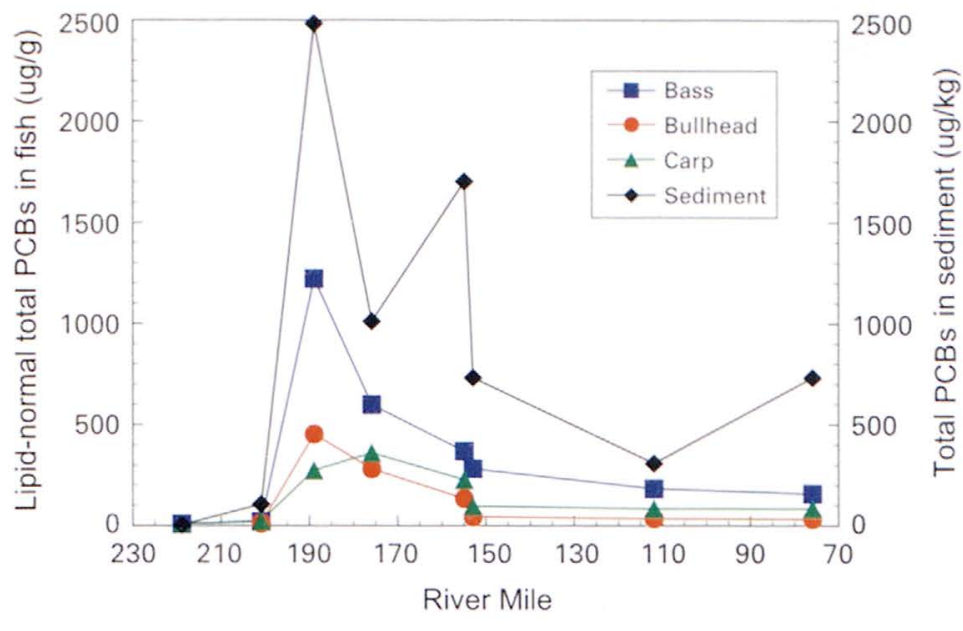

Figure 2. Mean lipid-based total PCB concentration in three fish species (sexes combined) and total PCB concentration in bed sediment at eight sites on the Hudson River, 1998. Sediment data are from 1998 collections, except Waterford (RM-155) and Poughkeepsie (RM-76) from 1993 samples and Feeder Dam (RM-201) from 1997 samples.

of endocrine biomarkers in individual fish may have on reproductive processes of fish populations in the Hudson River.

\section{References}

Baldigo, B.P., Sloan, R.J., Smith, S.B., and Keane, D.P., 2000, Polychlorinated biphenyls and endocrine biomarkers in fish from the Hudson River, New York, USA: Third SETAC World Congress-Society of Environmental Toxicology and Chemistry, May 21-25, 2000,

Brighton, United Kingdom.

Goodbred, S.L., Gilliom, R.J.,Gross, T.S., Denslow, N.P., Bryant, W.L., and Schoeb, T.R., 1997. Reconnaissance of 17- $\beta$ estradiol. 11 -

ketotestosterone, vitellogenin, and gonad histopathology in common carp of United States streams: potential for contaminant-induced endocrine disruption: U.S. Geological Survey Open-File Report 96-627, $47 \mathrm{p}$.

Phillips, P.J., Murray, K.R., Hollister, H.M., and Flanary, E.A., 1997. Distribution of DDT, chlordane, and total PCBs in bed sediments in the Hudson River basin: New York Earth Science and the Environment, vol. 3 , no. 1, p. 26-47.

Smith, S.B., Coles, J.F., Murray, K.R., Gross, T.S., and Denslow, N.P., 1997. Endocrine biomarkers for common carp (Cyprinus carpio) and largemouth bass (Micropterus salmoides) and their relationship to contaminants in tissue, sediments and water in northeastern United States rivers: Society of Environmental Toxicology and Chemistry, Nov. 1619. 1997, San Francisco, CA.

U.S. Environmental Protection Agency, 1997, Special report on environmental endocrine disruption: an effects assessment and analysis. U.S. Environmental Protection Agency, EPA/630/R-96/012, 116 p.

\section{For more information contact:}

Stephen B. Smith

US Geological Survey

MS 433 National Center

Reston, VA 20192

sbsmith@usgs.gov

Ronald J. Sloan

New York Department of

Environmental Conservation 50 Wolf Rd.

Albany, NY 12233

rjsloan@gw.dec.state.ny.us

Barry P. Baldigo

US Geological Survey

425 Jordan Rd.

Troy, NY 12180

bbaldigo@usgs.gov 